Fr. Piotr Kroczek

The Pontifical University of John Paul II in Krakow, Poland

\title{
State law as a determinant of church legislation: the case of Poland
}

Relations between Church and state have always been a complex issue. The history of the relations shows that the problem in question has had both theoretical and practical dimensions. ${ }^{1}$ The main reason for the sensitivity in the relations is that the Church and the state associate and rule the same people, but the origin, nature, and aims of the two subjects are different.

The aim of the paper is to present the problem of influence of state law on canon law as a part of the relations in question. The discussion presented in the paper is to refer to the current situation in Poland and relations of the Catholic Church and the Republic of Poland. Mutatis mutandis the principles of the Church and state relations and consequences of the relations for legislation can be applied to different religious organizations or different states.

\section{Church and state relations}

The point of departure for the deliberation of the problem formulated above must be a presentation of two models of the relations between the Catholic Church and the Republic of Poland - theological Catholic one, and Polish legal one.

1 R. Sobański, Problem stosunku Kościoła do państwa w teorii i w praktyce, "Prawo Kanoniczne" 35 (1992) no. 3-4, p. 9-23. 
The Second Vatican Council has finally rejected the model of the Church as societas perfecta, that is "a perfect state" which is quite similar to other (earthly) states. Nowadays, the Catholic Church understands itself more as a community than a state. Among many names, the Church describes itself as: mysticum Christi Corpus (the Mystical Body of Christ) ${ }^{2}$, Templum Spiritus Sancti (the Temple of the Holy Spirit), ${ }^{3}$ Populum Dei (the People of God). ${ }^{4}$ All these terms are to approach the mystery of the Church in many aspects and dimensions.

Such a deep self-awareness of the Church has implicated the change in the model of the relations of the Church with states. The modernized model is based on self-respect of the Church and respect for the other side, that is, the state. The pastoral Constitution on the Church in the modern world Gaudium et spes (1965) teaches that "The Church and the political community in their own fields are autonomous and independent from each other." It means that in their own fields the subjects must not purposely interfere one with another. In short, the Church and the state are exclusively competent in their own field, and consider themselves incompetent in the typical fields of the other society. ${ }^{6}$

The presented catholic model was recognized by Polish law. It seems that the Polish legislator has followed the modern ideas that the Church formulated in its teaching about rights and duties of the modern state, the place of the Church in the contemporary world and right for religious freedom.

2 Sacrosanctum Concilium Oecumenicum Vaticanum II, constitutio dogmatica Lumen gentium de Ecclesia [hereinafter: LG], 21.11.1964, AAS 57 (1965), p. 5-75, 8.

3 E.g. LG 17.

4 E.g. LG 11, 13.

5 Sacrosanctum Concilium Oecumenicum Vaticanum II, constitutio pastoralis Gaudium et spes de Ecclesia in mundo huius temporis, 7.12.1965, AAs 58 (1966), p. 1025-1115, no. 76; the literature of the subject is huge, e.g., J. Krukowski, Problematyka relacji między Kościołem i państwem na Soborze Watykańskim II, “Życie i Myśl” 12 (1980), p. 40-54.

English version of the documents of the Second Vatican Councils are cited from Documents of Vatican II, in a new and definitive translation, with commentaries and notes by Catholic, Protestant, and Orthodox authorities, gen. ed. W. M. Abbott, New York 1966.

6 J. Krukowski, Kościół i państwo. Podstawy relacji prawnych, Lublin 1993, p. 105. 
The Constitution of the Republic of Poland $1997^{7}$ provides for the freedom of religion that "shall be ensured to everyone." ${ }^{8}$ Part of the freedom is a possibility to create a Church and other religious organization. ${ }^{9}$

Due to art. 25 item 1 of the Polish Constitution (1997) - "Churches and other religious organizations shall have equal rights." Public authorities shall shape the relations between the Republic of Poland and churches and other religious organizations on the basis of the principle of respect for their autonomy and independence in its own sphere of activity. Relevant for the subject is the Act of 17 th May 1989 on the guarantees of the freedom of conscience and confession, ${ }^{10}$ which also refers to religious freedom, independence and autonomy of churches and other religious organizations from the Polish state. The two acts of law create the foundation for the state and any religious organization relations.

Due to the specificity of the Catholic Church - that enjoys sovereignty under international law similar to that of other states - the relations between the Republic of Poland and the Catholic Church are determined by the international treaty, that is, the Concordat of $1993 .{ }^{11}$ The legal act states in art. 1: "The Republic of Poland and the Holy See reaffirm that the State and the Catholic Church are, each in its own domain, independent and autonomous, and that they are fully committed to respecting this principle in all their mutual relations and in co-operating for the promotion of the benefit of humanity and the good of the community." ${ }^{12}$ In Polish legal system, there is also the Act

7 Konstytucja Rzeczypospolitej Polskiej z dnia 2 kwietnia 1997 r. (Dz.U. 1997 nr 78, poz. 483 z późn. zm.), [hereinafter: the Constitution (1997)]. English translation of the Constitution 1997 is taken from the official web side of the Polish Sejm (the lower chamber of the Polish parliament): http://www.sejm.gov.pl/prawo/konst/angielski/kon1.htm, 19.06.2013.

Nota bene: all Polish normative acts are published in the official organ that is Dziennik Ustaw Rzeczpospolitej Polskiej (“The Journal of Laws of the Republic of Poland”) [hereinafter: Dz.U.]. The publication journal is divided into numbers - "nr" and items "poz.. The expression "z późn. zm." means that a law was amended.

8 Art. 53 of the Constitution (1997).

9 Art. 2 item 1 of the Act of 17 th May 1989 on guarantees of the freedom of conscience and confession (Ustawa z dnia 17 maja 1989 o gwarancjach wolności sumienia i wyznania).

${ }^{10}$ Ustawa z dnia 17 maja 1989 r. o gwarancjach wolności sumienia i wyznania (Dz.U. nr 29, poz. $155 \mathrm{z}$ późn. zm.).

${ }_{11}$ Konkordat między Stolicą Apostolską i Rzecząpospolitą Polską, podpisany w Warszawie dn. 28 lipca 1993 r. (Dz.U. 1998 nr 51, poz. 318).

${ }_{12}$ Unofficial translation of the Concordat from http://pracownik.kul.pl/files/26914/public/ CONCORDAT.pdf, 12.07.2017. 
of 17 th May 1989 on the relationship between State and the Catholic Church in the Republic of Poland. ${ }^{13}$ (Nota bene fifteen Churches and other religious organizations enjoy the law like this). ${ }^{14}$ The law specifies the realm and ways of executing the presented above model of relations. Important for the subject matter of the paper is that art. 2 of the law states that: "The Church is governed by its own law, freely exercising its own spiritual and juridical powers, and managing its affairs." ${ }^{15}$

The conclusions is that there is no legal basis for the direct influence on church law by the state authorities or state law and, of course, vice versa.

The statement does not exclude the existence of two particular situations.

The first situation is that the Polish law incorporate to some extent the law of the Catholic Church (as well as law of other Churches and religious organizations). It happens under certain conditions. The first condition is that Polish law directly or indirectly refers to such law, and the second condition is that the range of the borrowing from religious law is strictly described and limited. The religious law does not act automatically in Polish law, but only under such conditions the religious law becomes a part of the Polish legal system. It happens most often in the case of definitions of terms, like "a clergy" (duchowny), "church service" (nabożeństwo) or "confesion" (spowiedź), which are used in the Polish laws, but the state legislator has no competency or/and will to define the terms.

The second situation is a reverse process. When the canon law remits some issue to the civil law, the latter must be observed by the Faithful with the

13 Ustawa z dnia 17 maja 1989 r. o stosunku Państwa do Kościoła Katolickiego w Rzeczypospolitej Polskiej (Dz.U. nr 29, poz. 154 z późn. zm.).

${ }^{14}$ For instance: the Act of 4th July 1991 on the relationship between the State and the Polish Autocephalous Orthodox Church (Ustawa z dnia 4 czerwca 1991 r. o stosunku Państwa do Polskiego Autokefalicznego Kościoła Prawosławnego, Dz.U. 1991 nr 66, poz. 287 z późn. zm.); the Act of 13 May 1994 on the relationship between the Evangelical Church of the Augsburg Confession in the Republic of Poland (Ustawa z dnia 13 maja 1994 r. o stosunku Państwa do Kościoła EwangelickoAugsburskiego w Rzeczypospolitej Polskiej, Dz.U. 1994 nr 73, poz. 323 z późn.).

For the survey of the laws and history of the Polish legislation in this matters see: P. Kroczek, Prawo wewnętrzne związków wyznaniowych $w$ perspektywie organów władzy publicznej. Klauzule generalne, Kraków 2017, p. 58-73.

15 “Kościół rządzi się w swych sprawach własnym prawem, swobodnie wykonuje władzę duchowną i jurysdykcyjną oraz zarządza swoimi sprawami” (transl. P. Kroczek). 
same effects as canon law, unless the civil law would be contrary to divine law or canon law (can. 22 CIC 1983). ${ }^{16}$

The question that arises is: How is it possible to discuss the state law as a determinant of the church legislations? To find answer to the question, first, one must look closer at canon law.

\section{Law as a part of Church's life}

Canon law in the catholic perspective is an indispensable part of Christ's Church, and it has been from the very beginning of the Church. According to the catholic teaching, canon law flows directly from the very nature of the Church - "Ius canonicum e natura Ecclesiae manare." ${ }^{\text {17 }}$ Law, as a phenomenon, is absolutely required to lead the faithful to salvation, ${ }^{18}$ and - as it was said by pope John Paul II in Praefatio to Codex Iuris Canonici 1983 - it is necessary so that the Church could „vigeat, crescat, floreat." ${ }^{\text {"19 }}$ "There is no Church without church law and vice versa."

Nota bene, it seems that the same is in the case of the Orthodox Churches. But, as a Zwischenruf, the Protestant view in the matter can be briefly presented. Rudolf Sohm (†1917) who was a German jurist, Church historian and Lutheran theologian, was completely against the Catholic understanding of law in the life of Church. The scholar in question said that the Church and law are two realities. They cannot be associated together. He summarized his opinion by saying that the nature of the Church and the nature of law are in contradiction. ${ }^{21}$

${ }^{16}$ Codex Iuris Canonici auctoritate Ioannis Pauli PP. II promulgatus, 25.01.1983, AAS 75 (1983) II, p. 1-301. English translation: Code of Canon Law Annotated, prepared under the Responsibility of the Instituto Martín de Azpilcueta, eds. E. Caparros, M. Thériault, J. Thorn, H. Aubé, Montréal 2004 .

${ }_{17}$ Praefatio, p. xx.

${ }_{18}$ P. Kroczek, Zasada "clara non sunt interpretanda" w prawie kanonicznym, Kraków $2005^{2}$, p. 96.

19 Praefatio to Codex Iuris Canonici auctoritate Ioannis Pauli PP. II promulgatus, AAS 75 (1983) pars II, p. XXX.

${ }^{20}$ P. Kroczek, The Art of Legislation: The Principles of Lawgiving in the Church, Kraków 2012, p. 36 .

${ }^{21}$ R. Sohm, Kirchenrecht, vol. 1: Die geschichtlichen Grundlagen, Leipzig 1923, p. 700: "Das Wesen der Kirche ist geistlich, das Wesen des Rechtes ist weltlich. Das Wesen des Kirchenrechtes steht mit dem Wesen der Kirche in Widerspruch." 
His position has been widely criticized, even by the protestants themselves. ${ }^{22}$ For instance, Karl Barth (†1968) an acclaimed Swiss Protestant theologian, wrote that „R. Sohma's thesis is certainly delusional, since the first church had at least the canonical order, that is, the Apostles and the People!" ${ }^{23}$ It has been pointed out that Rudolf Sohm used an inadequate method. Firstly, he held an incorrect concept of the Church, seeing it only as a spiritual reality. He presumed that the early Church was a fully and only charismatic and non-juridical organism. Secondly, he misunderstood the law. He took the definition of law from a strongly positivistic approach. Despite the criticisms, Rudolf Sohms's ideas are still representative of some of the Protestant Churches. ${ }^{24}$

Continuing the main stream of the deliberations, it must be noticed that the nature of the Church and, following it, the nature of canon law implies a very important issue - canon law, as it is in case of the Church, must be open to the world and conduct a dialogue with the world. Openness and stance of dialog of canon law and the world can be seen in two different factors. The first is legal theory, and the second is the concrete regulations of law. Both will be discussed in the paper.

\section{Determinants of legislation in general}

A part of legal theory are deliberations over legislation understood here as a process of drafting law. The process in question depends on many determinants, which shape mainly the regulations. Sometimes the determinants have influence also on the drafting proceedings. Numerous factors can be listed as determinants of the legislative process as whole. It can be said that the more factors are taken into consideration by the legislator, the more conscious and intentional the process of drafting law will be, producing as a result a law which would serve better the addressees.

Although the legislator is a specialist in law and his competences are in the realm of law, there is nothing more dangerous than a specialist who is not

${ }^{22}$ See: Y. Congar, R. Sohm nous interroge encore, "Revue des Sciences Philosophiques et Théologiques" 57 (1973), p. 263-294, and bibliography on p. 287-294.

${ }^{23}$ K. Barth, Dogmatyka w zarysie, tłum. I. Nowicka, Warszawa 1994, p. 146: “Teza R. Sohma to z pewnością urojona sprawa, gdyż już pierwsza gmina miała przynajmniej porządek kanoniczny Apostołów oraz lud!" (transl. P. Kroczek).

${ }^{24}$ The analises of the attitudes of the religious organizations to law, see: P. Kroczek, Prawo wewnętrzne związków wyznaniowych $w$ perspektywie organów władzy publicznej. Klauzule generalne, Kraków 2017, p. 105-114. 
referring to other sciences or has no common experience at all. ${ }^{25}$ The more achievements of arts and sciences are taken into consideration in his work, and the more he knows about the life of the addressees of the law, it is the more probable that a law drafted by him would realize successfully its aims and would appropriately answer the needs of the society. It is important because law is in fact a very interdisciplinary science. Jurisprudence speaks a lot about benefits that come from the openness of law to achievements of other sciences. ${ }^{26}$ The broader horizons the legislator has, the better quality of law produced by him. ${ }^{27}$

The same rule is valid in case of canon law. Collecting and accumulating knowledge, facts, ideas and inspirations from many different arts and sciences, that is, the openness of law to other disciplines of learning can be called interdisciplinarity of canon law. The desire for familiarity of the legislator with works of other scholars from different fields of knowledge such as: theology, philosophy, jurisprudence, political science, linguistics, sociology, economy, and technology, ${ }^{28}$ must not be understood as ambition to keep up with them. Any borrowing from them must be done selectively, because due to specificity of law in the Church not everything fits the canon law. The criteria are in the nature of canon law and its aim, that is, fostering the care of souls and, ultimately, bringing the souls to salvation, as it was formulated by St. Ivo of Chartres: "Cum ergo omnis institutio ecclesiasticarum legum ad salutem referenda sit animarum"29 (cf. can. 1752).

\section{State law as a determinant for canon law}

The nature of the canon law and its aims require from the legislator to be open and be vigilant and constantly follow the changes also in the state legislation, especially in the realm of the matters regulated both by the state and Church (so called res mixtae). The Church must not omit anything what is important for itself as an institution and for the faithful as a community. The legislator

${ }_{25}$ Cf. L. Örsy, Quantity and Quality of Laws after Vatican II, “The Jurist” 27 (1967), p. 406-407.

${ }^{26}$ K. Junker, Law and Science Serving One Master... narrative, [in:] Communicating Science: Professional Contexts, eds. E. Scanlon, R. Hill, K. Junker, London 1999, p. 249-269; J. Gaakeer, Introduction. Multi and Interdisciplinary: mere Theory or Just Practice?, "Erasmus Law Review" (2008) no. 3, p. 1-2.

${ }^{27}$ Cf. L. Örsy, The Interpreter and His Art, “The Jurist" 40 (1980), p. 50.

28 P. Kroczek, Zagadnienie interdyscyplinarności prawa, "Polonia Sacra” 26 (2010), p. 169-182.

${ }^{29}$ Ivo Carnotensis, Epistola, no. 6o, [in:] Patrologiae cursus completus, ed. J.-P. Migne, vol. 162, Paris 1885, col. 74. 
is the Head of the community and part of his task is to be on the lookout as spiritual shepherds are.

\section{Casus - current situation in Poland}

As it was announced, an example of the stale law as determinant for canon law, will be provided. This requires a short historical introduction.

In 2001 Pope John Paul II promulgated the Apostolic letter motu proprio Sacramentorum sanctitatis tutela ${ }^{30}$ to safeguard the Sanctity of the Sacraments, especially the Most Holy Eucharist and Penance, and the keeping of the faithful, called to communion with the Lord, in their observance of the sixth commandment of the Decalogue. On the force of the law the Congregation for the Doctrine of the Faith is also able to examine delicts against morals and proceeds to declare or impose canonical sanctions according to the norm of both common or proper law. In this matter, the Congregation was given the judicial competence as the Apostolic Tribunals do. By this document, the Pope also promulgated Norms concerning the more grave delicts reserved to the Congregation for the Doctrine of the Faith (Normae de gravioribus delictis Congregationi pro Doctrina Fidei reservatis).

Next, in 2010 the Congregation for the Doctrine of the Faith issued some amendments to Normae de gravioribus delictis. ${ }^{31}$ The modifications were of procedural and executional character. Their aim was to eradicate canonical crimes in the Church more efficiently, especially the offenses against the Sixth Commandment with a minor below the age of sixteen years. Norms in question in art. 13 state that whenever the Ordinary or Hierarch receives a report of a reserved delict which has at least a semblance of truth (notitiam saltem verisimilem) he must carry out the preliminary investigation and after it has been completed, he is to communicate the matter to the Congregation for the Doctrine of the Faith.

30 Joannes Paulus PP. II, litterae apostolicae motu proprio datae Sacramentorum sanctitatis tutela quibus normae de gravioribus delictis congregationi pro Doctrina Fidei reservatis promulgantur, AAS 93 (2001), p. 737-739. English translation: http://w2.vatican.va/content/john-paul-ii/en/ motu_proprio/documents/hf_jp-ii_motu-proprio_20020110_sacramentorum-sanctitatis-tutela. html, 12.07.2017.

${ }^{31}$ Congregatio Pro Doctrina Fidei, Normae de gravioribus delictis, 21.05.2010, AAS 102 (2010), p. $419-434$. 
In order to come to the aid of the persons who have had a preliminary canonical inquiry, the Episcopal Conference of Poland issued in 2014 the Guidelines for initial canonical inquiry in the case of clerical accusations of deeds against the Sixth Commandment of the Decalogue with a minor under the age of eighteen..$^{32}$ The document is announced as a binding law in the Catholic Church in Poland. It is important to notice that the document in original version did not deal with the issue of the cooperation with state authorities.

In 2017 Polish legislator made an amendment to the Criminal Code. The new version art. $240^{33}$ of the code in question penalizes the situation when somebody knowing about some criminal offences listed in the article - among them is a sexual abuse of minors below 15 years of age - does not report it to the state authorities, such as Police or district attorney. ${ }^{34}$ The penalty for not fulfilling the duty was up to three years of imprisonment. The change in the Criminal Code has been effective from 13.07.2017.

Due to the new regulation the Episcopal Conference decided to change the Guidelines. It was done on 6.06.2017..$^{35}$ The reason for the action was not explained by the church legislator himself, anyway it can be quite easily deducted. The Church changed its Guidelines to protect people who are on behalf of the Church involved in the investigation of the cases of sexual abuse of minors. The lack of the amendment in Guidelines could cause the situation that the people in question and their church supervisors observing canon would be in jeopardy from the Polish law. Canon law so far required to keep the information

${ }^{32}$ Wytyczne dotyczące wstępnego dochodzenia kanonicznego w przypadku oskarżeń duchownych o czyny przeciwko szóstemu przykazaniu Dekalogu z osoba niepelnoletnia poniżej osiemnastego roku życia, "Akta Konferencji Episkopatu Polski" (2015) no. 27, p. 39-49, http://episkopat.pl/wytycznedotyczace-wstepnego-dochodzenia-kanonicznego-w-przypadku-oskarzen-duchownych-o-czynyprzeciwko-szostemu-przykazaniu-dekalogu-z-osoba-niepelnoletnia-ponizej-osiemnastego-rokuzycia, 22.05.2017 [hereinafter: Guidelines].

33 "Kto, mając wiarygodną wiadomość o karalnym przygotowaniu albo usiłowaniu lub dokonaniu czynu zabronionego określonego w art. 118, art. 118a, art. 120-124, art. 127, art. 128, art. 130, art. 134, art. 140, art. 148, art. 156, art. 163, art. 166, art. 189, art. $197 \$ 3$ lub 4, art. 198, art. 200, art. 252 lub przestępstwa o charakterze terrorystycznym, nie zawiadamia niezwłocznie organu powołanego do ścigania przestępstw, podlega karze pozbawienia wolności do lat 3.”

34 The amendment was introduced by Ustawa $\mathrm{z}$ dnia 23 marca 2017 r. o zmianie ustawy - Kodeks karny, ustawy o postępowaniu w sprawach nieletnich oraz ustawy - Kodeks postępowania karnego (Dz.U. 2017 poz. 773).

35 Unified version of Wytyczne on the page: http://episkopat.pl/wp-content/uploads/2017/o7/ KEP_wytyczne_z_aneksami.NOWELIZACJA.2017-1.pdf, 13.07.2017. 
gathered during the canonical inquiry for the church internal usage only (no. 16 and no. 2 item 3 of Guidelines).

Currently, Guidelines orders that lawful superior of the Local Church is to inform (by the Plenipotentiary) the state authorities about every situation of the character of criminal crime listed in art. 240 of the Criminal Code, unless it is known for sure that the authorities know about the case (art. 1a item 1 of Guidelines). The Plenipotentiary shall promptly notify in writing the state authorities, stating:1) data of alleged perpetrator; 2) general description of the forbidden act; 3 ) the name of the alleged victim; 4) details of the person from whom the information was obtained. The Plenipotentiary shall receive an official acknowledgment of the notification (art. 1a item 2 and 3 of Guidelines). Also the accuser must be clearly reminded of his/her obligation to report to law enforcement authorities the case, in accordance with Polish law. If the accuser has not yet done so, the obligation also applies to the person who on behalf of the Church accepts the denunciation (no. 4 of Guidelines).

It must be noticed that the requirement of the state law is strengthened by canon law. It can be a good sign that the protection of children in the future will be more guarded because both, the state and the Church, take simultaneously care of it.

\section{Conclusions}

The conclusion is that the legislation, also in case of the Catholic Church, is an art. It requires from the church legislator, among so many skills, to be knowledgeable about the state law. The motivation for following the changes in state law must not be only erudition or general legal knowledge. It has a very theological and practical dimension - to foster a good care for the People of God. The church legislator, who wants to be a good Shepherd of his Flock must be vigilant and constantly monitor the legislative work of the legislative state organs.

The postulate in the matter can be formulated as follows: legislative body of the Episcopal Conference, in case of the Polish Episcopal Conference it is the Council for Legal Affairs (Komisja Prawna Episkopatu), must be charged with the duty of following legislative work of state legislator. It is expedient that it would be implemented in the statute or the proceedings of the body.

In polish circumstances another two bodies could be involved in the process of following the Polish legislation - the Common Commission of the Representatives of the Government of the Republic of Poland and Episcopate 
(Komisja Wspólna Przedstawicieli Rządu Rzeczpospolitej Polskiej i Episkopa$t u$ ) and the Concordat Commission (Komisja Konkordatowa). The first body was founded 1949 as a platform for talks with the socialist government. The last body's aim was a realization of the Concordat and it was erected after the ratification of Concordat in 1998.

The same duty can be imposed by the Conference of Bishops on diocesan bishops, who are the legislators of their dioceses on the local level: such as area development plan, local taxes, or anything that can have influence on the Church.

\section{Extra: Ecumenical perspective}

An ecumenical element can be pointed out here as a postulate. In Poland, there is the Polish Ecumenical Council (Polska Rada Ekumeniczna). The body was founded in 1946 to promote inter-church cooperation. Today the council includes seven major Christian churches, except the Catholic Church. The Catholic Church is not a member of the body in question, but cooperates with the Council. On the catholic side, the organ that is called to cooperate with the council is the Group for Contacts with the Polish Ecumenical Council (Zespót ds. Kontaktów z Polska Radą Ekumeniczną).

There are still many unexploited fields for cooperation between the Catholic Church and the Council. It is not hard to find some examples among the following matters: protection of personal data, cemeteries and burial of the deceased, public gatherings, taxes, pro-family politics. All of them should be of common interest among the Christian Churches, especially in the face of secularization or disapproving and unfavorable state laws. It seems that standing together and creating the Christian lobby for pressing on the Parliament is a very rational way of acting.

It can be mentioned that the presented problem refers not only to Poland, but it can also be seen on the UE level.

\section{ABstract}

A part of the relation between Church and state are interrelations between their systems of law. The aim of the paper is to present the problem of influence of state law on canon law. The discussion presented in the paper is to refer to the current situation in Poland and relations of the Catholic Church and the Republic of Poland. 
Document issued by the Episcopal Conference of Poland titled "The Guidelines for initial canonical inquiry and in the case of clerical accusations of deeds against the Sixth Commandment of the Decalogue with a minor under the age of eighteen" (2014) and the amends to it is an example. The conclusion is that the church legislator, who wants to be a good Shepherd of his Flock is to be knowledgeable about the state law and must be vigilant and constantly monitor the legislative work of the legislative state organs. The postulate in the matter can be formulated especially for the legislative body of the Episcopal Conference that is the Council for Legal Affairs. Mutatis mutandis the principles of the Church and state relations and consequences of the relations for legislation can be applied to different religious organizations or different states.

\section{KEY WORDS}

state law, canon law, state and Church relations, legislation

\section{ABSTRAKT}

\section{Prawo państwowe jako determinant prawodawstwa}

\section{kościelnego. Przypadek Polski}

Częścią relacji między Kościołem a państwem są wzajemne zależności między ich prawnymi systemami. Celem artykułu jest przedstawienie problemu wpływu prawa państwowego na prawo kanoniczne. W artykule omówiona została aktualna sytuacja w Polsce pomiędzy Kościołem katolickim i Rzecząpospolitą Polską. Dokument wydany przez Konferencję Episkopatu Polski zatytułowany „Wytyczne dotyczące wstępnego dochodzenia kanonicznego w przypadku oskarżeń duchownych o czyny przeciwko szóstemu przykazaniu Dekalogu z osobą niepełnoletnią poniżej osiemnastego roku życia” (2014) i zmiany w nim dokonane są ilustracją tego oddziaływania. Wniosek z przeprowadzonych rozważań jest następujący: prawodawca kościelny, który chce być dobrym pasterzem swojego stada, powinien mieć wiedzę na temat prawa państwowego. Musi on być czujny i stale monitorować prace państwowych organów ustawodawczych. Postulat w tej materii może być sformułowany specjalnie wobec organu legislacyjnego Konferencji Episkopatu, czyli Rady Prawnej. Mutatis mutandis zasady relacji Kościoła i państwa oraz konsekwencje działalności prawodawczych Kościoła można zastosować do różnych związków wyznaniowych lub różnych państw.

\section{SŁOWA KLUCZOWE}

prawo państwowe, prawo kanoniczne, relacje państwo-Kościół, legislacja 


\section{BIBLIOGRAPHY}

Barth K., Dogmatyka w zarysie, tłum. I. Nowicka, Warszawa 1994.

Codex Iuris Canonici auctoritate Ioannis Pauli PP. II promulgatus, 25.01.1983, AAS 75 (1983) II, p. 1-301. English translation: Code of Canon Law Annotated, prepared under the Responsibility of the Instituto Martín de Azpilcueta, eds. E. Caparros, M. Thériault, J. Thorn, H. Aubé, Montréal 2004.

Congar Y., R. Sohm nous interroge encore, "Revue des Sciences Philosophiques et Théologiques" 57 (1973), p. 263-294.

Congregatio Pro Doctrina Fidei, Normae de gravioribus delictis, 21.05.2010, AAS 102 (2010), p. 419-434.

Gaakeer J., Introduction. Multi and Interdisciplinary: Mere Theory or Just Practice?, “Erasmus Law Review” (2008) no. 3, p. 1-2.

Joannes Paulus PP. II, Litterae apostolicae motu proprio datae Sacramentorum sanctitatis tutela quibus normae de gravioribus delictis congregationi pro Doctrina Fidei reservatis promulgantur, AAS 93 (2001), p. 737-739. English translation: http:// w2.vatican.va/content/john-paul-ii/en/motu_proprio/documents/hf_jp-ii_motu-proprio_20020110_sacramentorum-sanctitatis-tutela.html.

Junker K., Law and Science Serving One Master... narrative, [in:] Communicating Science: Professional Contexts, eds. E. Scanlon, R. Hill, K. Junker, London 1999, p. 249-269.

Konkordat między Stolicą Apostolską i Rzecząpospolitą Polską, podpisany w Warszawie dnia 28 lipca 1993 r. (Dz.U. 1998 nr 51, poz. 318).

Konstytucja Rzeczypospolitej Polskiej z dnia 2 kwietnia 1997 r. (Dz.U. nr 78, poz. 483 z późn. zm.).

Kroczek P., Prawo wewnętrzne związków wyznaniowych w perspektywie organów władzy publicznej. Klauzule generalne, Kraków 2017.

Kroczek P., The Art of Legislation: The Principles of Lawgiving in the Church, Kraków 2012.

Kroczek P., Zagadnienie interdyscyplinarności prawa, "Polonia Sacra" 26 (2010), p. $169-182$.

Kroczek P., Zasada "clara non sunt interpretanda" w prawie kanonicznym, Kraków $2005^{2}$.

Krukowski J., Kościół i państwo. Podstawy relacji prawnych, Lublin 1993.

Krukowski J., Problematyka relacji między Kościołem i państwem na Soborze Watykańskim II, “Życie i Myśl” 12 (1980), p. 40-54.

Örsy L., Quantity and Quality of Laws after Vatican II, “The Jurist” 27 (1967), p. 385412. 
Örsy L., The Interpreter and His Art, "The Jurist" 40 (1980), p. 27-56.

Praefatio to Codex Iuris Canonici auctoritate Ioannis Pauli PP. II promulgatus, A AS 75 (1983) pars II, p. XV-XXX.

Sacrosanctum Concilium Oecumenicum Vaticanum II, Constitutio dogmatica Lumen gentium de Ecclesia, 21.11.1964, AAS 57 (1965), p. 5-75.

Sacrosanctum Concilium Oecumenicum Vaticanum II, Constitutio pastoralis Gaudium et spes de Ecclesia in mundo huius temporis, 7.12.1965, A AS 58 (1966), p. 1025-1115.

Sobański R., Problem stosunku Kościoła do państwa w teorii $i$ w praktyce, "Prawo Kanoniczne" 35 (1992) no. 3-4, p. 9-23.

Sohm R., Kirchenrecht, vol. 1: Die geschichtlichen Grundlagen, Leipzig 1923.

Ustawa z dnia 17 maja 1989 o gwarancjach wolności sumienia i wyznania (Dz.U. nr 29, poz. 155 z późn. zm.).

Ustawa z dnia 17 maja 1989 r. o stosunku Państwa do Kościoła Katolickiego w Rzeczypospolitej Polskiej (Dz.U. nr 29, poz. 154 z późn. zm.).

Ustawa z dnia 23 marca 2017 r. o zmianie ustawy - Kodeks karny, ustawy o postępowaniu w sprawach nieletnich oraz ustawy - Kodeks postępowania karnego (Dz.U. 2017 poz. 773).

Ivo Carnotensis, Epistola, no. 6o, [in:] Patrologiae cursus completus, ed. J.-P. Migne, vol. 162, Paris 1885.

Wytyczne dotyczące wstępnego dochodzenia kanonicznego w przypadku oskarżeń duchownych o czyny przeciwko szóstemu przykazaniu Dekalogu z osoba niepetnoletnia poniżej osiemnastego roku życia, "Akta Konferencji Episkopatu Polski” (2015) no. 27, p. 39-49, http://episkopat.pl/wytyczne-dotyczace-wstepnego-dochodzenia-kanonicznego-w-przypadku-oskarzen-duchownych-o-czyny-przeciwko-szostemu-przykazaniu-dekalogu-z-osoba-niepelnoletnia-ponizej-osiemnastego-roku-zycia. 